\title{
Clinical applications of palmitoylethanolamide in pain management: protocol for a scoping review
}

\author{
Maria Beatrice Passavanti ${ }^{1}$, Aniello Alfieri ${ }^{1}$, Maria Caterina Pace ${ }^{1}$, Vincenzo Pota ${ }^{1}$, Pasquale Sansone \\ Giacomo Piccinno ${ }^{1}$, Manlio Barbarisi ${ }^{2}$, Caterina Aurilio ${ }^{1}$ and Marco Fiore ${ }^{1 *}$ (D)
}

\begin{abstract}
Background: Palmitoylethanolamide (PEA) belong to endocannabinoid family, a group of fatty acid amides. PEA has been proven to have analgesic and anti-inflammatory activity and has been used in several controlled studies focused on the management of chronic pain among adult patients with different underlying clinical conditions.

Methods/design: A literature search will be performed using PubMed, EMBASE, and the Cochrane Central Register of Controlled Trials (CENTRAL). The population will be patients who have chronic pain, the intervention will be the administration of PEA alone or in combination with other drugs for the pain management; the comparison will be the standard therapy in accordance with the current guidelines for the treatment of pain. The Outcomes will be the reduction of pain not restricted to specific scales laying out the pain outcome data described in the included studies.
\end{abstract}

Discussion: This scoping review aims to describe the clinical applications of the PEA in chronic pain management and its outcome.

Scoping review registration: Open Science Framework https://osf.io/74tmx/.

Keywords: Palmitoylethanolamide, Systematic review, PEA, Pain, Pain management, Endocannabinoids, Ethanolamines, Humans, Palmitic acids, Palmidrol

\section{Background}

Palmitoylethanolamide (PEA) is an endogenous fatty acid amide, an analog of the endocannabinoid anandamide (AEA), that belongs to the family of $\mathrm{N}$-acylethanolamines (NAE) [1]. NAEs are released from cells in response to noxious stimuli. As all NAEs, also the PEA has a local effect, and its tissue levels are closely regulated through the balance of production and degradation activity. Two intracellular amidases, expressed in the inflammatory cells, have been involved in lipid amide degradation: fatty-acid amide hydrolase (FAAH) and $\mathrm{N}$-acylethanolamine hydrolyzing acid amidase (NAAA) [2].

\footnotetext{
* Correspondence: marco.fiore@unicampania.it

${ }^{1}$ Department of Women, Child and General and Specialized Surgery, University of Campania "Luigi Vanvitelli", Piazza L. Miraglia, 2, 80138 Naples, Italy

Full list of author information is available at the end of the article
}

The effects of the PEA are due to its interaction with several pathways: at first, it reduces, via the peroxisome proliferator-activated receptor alpha (PPAR $\alpha)$, the recruitment and activation of mast cells at sites of nerve injury and the release of pro-inflammatory mediators from these cells $[3,4]$; secondly, it inhibits the microglia activation and the recruitment of mast cells into spinal cord after peripheral nerve injury, as well as following spinal neuroinflammation or spinal cord injury $[5,6]$. In the beginning, PEA was also supposed to be an agonist of the cannabinoid type II receptor (CB2) [7]; subsequently, in their research, Sugiura et al. have demonstrated that PEA has just a very low affinity for this receptor [8], clarifying why $\mathrm{CB} 2$ antagonists do not inhibit some of its anti-inflammatory effects [9]. Anyhow, PEA indirectly activates $\mathrm{CB} 2$ and the cannabinoid receptor type 1 (CB1) [10], down-modulating fatty acid amide

(C) The Author(s). 2019 Open Access This article is distributed under the terms of the Creative Commons Attribution 4.0 International License (http://creativecommons.org/licenses/by/4.0/), which permits unrestricted use, distribution, and reproduction in any medium, provided you give appropriate credit to the original author(s) and the source, provide a link to the Creative Commons license, and indicate if changes were made. The Creative Commons Public Domain Dedication waiver (http://creativecommons.org/publicdomain/zero/1.0/) applies to the data made available in this article, unless otherwise stated. 
hydrolase (FAAH), the enzyme responsible of the degradation of the anandamide (AEA), a CB1 agonist [11].

Several studies focused on the use of PEA in a multitude of chronic pain conditions. For example, it can have a beneficial effect like adjuvant for the treatment of the low back pain [12] or it was used alone for chronic pain management in critically ill older patients, where the use of traditional analgesics can lead to high risk of adverse effect [13]. Encouraging results have been shown in the treatment of non-surgical radiculopathies with an ultra-micronized formulation of PEA [14] and the combination therapy with alpha-lipoic acid to reduce chronic prostatitis/chronic pelvic pain syndrome [15].

\section{Importance of this review}

Although pharmacological pain therapy offers several alternatives, pain management remains often unsatisfactory. In order to reinforce the therapeutic solutions, the use of the PEA for the treatment of chronic or inflammatory pain may be a valid strategy. To our knowledge, this is the first scoping review that summarizes the literature findings on the use of PEA in chronic pain management.

\section{Methods/design}

\section{Research questions}

This review is designed to answer the following research question:

\section{What are the current clinical applications of PEA in the management of chronic pain?}

We will prepare this scoping review according to the Preferred Reporting Items for Systematic Reviews and Meta-Analysis Extension for Scoping Reviews (PRISMA-ScR) [16].

\section{Searching}

A literature search will be performed using several computer-assisted databases, including PubMed, EMBASE, and the Cochrane Central Register of Controlled Trials (CENTRAL). To the results, we will add the publications cited in articles obtained by primary research, previous reviews, or books to identify additional eligible studies.

The search strategy and the search string will be formulated following the PICO method.

The Population will be patients who have chronic pain, and the Intervention will be the administration of PEA alone or in combination with other drugs for the treatment of pain. The Comparator will be the standard therapy in accordance with the current guidelines for the treatment of pain. The Outcomes will be pain reduction measured with any type of pain assessment scale.
Computer searches will be performed using the following search string: "palmitoylethanolamide" AND "pain."

The reference list of the retrieved articles will be used to find relevant studies that will be not allocated through the searching procedure. We will not restrict the search with any filter. Duplicates will be removed after the literature search, and two reviewers (AA and GP) will independently conduct a two-stage screening reading the titles and abstracts identified in the search strategy detailed above. Each title will be screened using a screening guide. Titles will be retained if they appear to meet the inclusion criteria or if it is uncertain if they do (Table 1).

\section{Eligibility criteria}

To be included in the review, studies will need to have a control group, in which patients with chronic pain are explicitly treated with PEA, with no restrictions on publication year. We will exclude unpublished works as a full-text, abstract, conference meetings, studies published in not peer-review journals, uncontrolled studies as case series or case reports, reviews, and studies published not in English.

Papers will be excluded if they do not fit into the conceptual framework of the study, focused on chronic pain management.

\section{Primary abstract screening}

Initially, the articles will be selected by the authors assessing titles and abstracts to identify potentially eligible studies; then, the full-text of the eligible studies will be reviewed by the authors to exclude irrelevant studies or methodologies not being a useful motivation for future analysis.

\section{Methods for data extraction}

The reviewers will record key information from included articles in a Microsoft Excel data extraction form designed a priori. Two reviewers (AA and GP) will independently extract data to minimize errors. Each study will be extracted with the following information: title, year of publication, first author, the country where the study was conducted, type of study, lying chronic disease for which the PEA was used, and outcome.

\section{Strategy for data synthesis}

The number of studies identified and selected at each stage of the scoping review and the reasons for exclusion will be presented in a PRISMA flow diagram. Results will be summarized in table form (Table 2) and discussed deeper in narrative form to address the research questions. Results will be grouped conceptually, by general study details, study characteristics, participants, interventions/exposures/comparators, instruments used in 
Table 1 Eligibility criteria

\begin{tabular}{|c|c|c|}
\hline & Inclusion & Exclusion \\
\hline $\begin{array}{l}\text { Study } \\
\text { design }\end{array}$ & $\begin{array}{l}\text { Primary studies of any } \\
\text { design that includes a } \\
\text { control group }\end{array}$ & Systematic reviews \\
\hline Population & $\begin{array}{l}\text { Patients who have chronic } \\
\text { pain }\end{array}$ & $\mathrm{n} / \mathrm{a}$ \\
\hline $\begin{array}{l}\text { Intervention/ } \\
\text { exposure }\end{array}$ & $\begin{array}{l}\text { Administration of PEA alone } \\
\text { or in combination }\end{array}$ & $\mathrm{n} / \mathrm{a}$ \\
\hline Outcomes & $\begin{array}{l}\text { Pain reduction assessed } \\
\text { with all approaches } \\
\text { available for assessing pain } \\
\text { intensity }\end{array}$ & $\begin{array}{l}\text { Anything other than the } \\
\text { selected outcomes }\end{array}$ \\
\hline Language & English & $\begin{array}{l}\text { Anything other than } \\
\text { English }\end{array}$ \\
\hline $\begin{array}{l}\text { Publication } \\
\text { status }\end{array}$ & $\begin{array}{l}\text { Published in peer review } \\
\text { journals, full-length articles }\end{array}$ & $\begin{array}{l}\text { Published in not peer- } \\
\text { review journals, unpub- } \\
\text { lished works as a full-text, } \\
\text { abstract, conference } \\
\text { meetings }\end{array}$ \\
\hline Others & $\begin{array}{l}\text { All study dates, length of } \\
\text { follow-up, setting }\end{array}$ & $\mathrm{n} / \mathrm{a}$ \\
\hline
\end{tabular}

goal-setting, outcomes, and results. This review will present summaries of these categories, including quantitative measurements of associations (mean differences for scores by validated questionnaires, risk ratios, or odds ratios for dichotomous outcomes), if applicable.

Table 2 Planned variables to be extracted in the scoping review

\begin{tabular}{ll}
\hline General study details & Study ID number, lead author, title, journal, year of \\
publication, type of publication, information source \\
Study characteristics & Study design, study duration, pilot/feasibility study \\
& (y/n), number of study arms, covariates (definition \\
and measurement \\
methods) \\
1. Total number, setting, inclusion and exclusion \\
criteria \\
2. Participant characteristics at baseline: for each \\
study, average age (years, mean and standard \\
deviation [SD]), sex (\%), country, and time since \\
diagnosis (or time since treatment, if treatment was \\
completed) \\
1. Total number of intervention/exposure and \\
comparison groups and number of participants in \\
each group \\
2. For each intervention/exposure and comparison \\
group: intervention/exposure/comparison, duration \\
of intervention/exposure, who and how assessed, \\
and results of assessment \\
The approach used in the study for assessing pain \\
intensity including categorical scales (e.g., mild, \\
moderate, severe), numerical rating scales (NRS), \\
visual analog scales (VAS), and well-validated verbal \\
scales (eg, the Descriptor Differential Scale). \\
For each quantitative outcome: sample size, number \\
of missing participants, reasons for loss to follow up, \\
summary \\
data for each group (2 $\times 2$ table for dichotomous \\
data, means and SDs for continuous data), estimate \\
of effect for the difference between groups (or \\
change in baseline and final scores for single-arm \\
studies), confidence intervals, and $p$ value
\end{tabular}

Additional groups may be identified during the extraction of results.

Authors of papers will be contacted to request missing or additional data for clarification, where required. We will report the results of critical appraisal in narrative form and in a table.

The final protocol was registered prospectively with the Open Science Framework on 12 December 2018 (https://osf.io/74tmx/).

\section{Discussion}

This protocol is for a scoping review that is planned and not started. This scoping review aims to describe the clinical applications of the PEA in pain management of different chronic diseases and its outcome.

\section{Abbreviations}

AEA: Anandamide; CB1: Cannabinoid type I receptor; CB2: Cannabinoid type II receptor; CENTRAL: Cochrane Central Register of Controlled Trials; FAAH: Fatty-acid amide hydrolase; NAAA: N-acylethanolamine hydrolyzing acid amidase; NAE: N-acylethanolamines; PEA: Palmitoylethanolamide; PPARa: Peroxisome proliferator-activated receptor alpha; PRISMA-P: Preferred Reporting Items for Systematic Reviews and Meta-Analysis Protocols; VAS Pain: Visual Analog Scale for Pain

\section{Funding}

There is no funding related to this manuscript to declare.

\section{Availability of data and materials}

The datasets generated and/or analyzed during the current study are available from the corresponding author on reasonable request.

\section{Authors' contributions}

This study was mainly written by MF, AA, and MBP. AA and GP collected the data. CA and MCP supervised the writing of the paper. PS, VP, and MB critically revised the paper. All authors gave final approval of the version to be published and agreed to be accountable for all aspects of the work.

Ethics approval and consent to participate

Not applicable

\section{Consent for publication}

Not applicable

\section{Competing interests}

The authors declare that they have no competing interests related to this manuscript.

\section{Publisher's Note}

Springer Nature remains neutral with regard to jurisdictional claims in published maps and institutional affiliations.

\section{Author details}

${ }^{1}$ Department of Women, Child and General and Specialized Surgery, University of Campania "Luigi Vanvitelli", Piazza L. Miraglia, 2, 80138 Naples, Italy. ${ }^{2}$ Department of Medical, Surgical, Neurological, Metabolic and Aging Sciences, University of Campania "Luigi Vanvitelli", Piazza L. Miraglia, 2, 80138 Naples, Italy.

Received: 20 January 2018 Accepted: 26 December 2018

Published online: 08 January 2019

\section{References}

1. Hansen HS. Palmitoylethanolamide and other anandamide congeners. Proposed role in the diseased brain. Exp Neurol. 2010;224(1):48-55 https:// doi.org/10.1016/j.expneurol.2010.03.022. 
2. Petrosino S, luvone T, Di Marzo V. N-palmitoyl-ethanolamine: biochemistry and new therapeutic opportunities. Biochimie. 2010;92(6):724-7 https://doi. org/10.1016/j.biochi.2010.01.006.

3. Cerrato S, Brazis P, della Valle MF, Miolo A, Puigdemont A. Effects of palmitoylethanolamide on immunologically induced histamine, PGD2 and TNFa release from canine skin mast cells. Vet Immunol Immunopathol. 2010;133(1):9-15 https://doi.org/10.1016/j.vetimm.2009.06.011.

4. Costa B, Colombo A, Bettoni I, Bresciani E, Torsello A, Comelli F. The endogenous ligand palmitoylethanolamide relieves neuropathic pain via mast cell and microglia modulation. 21st Annual Symposium Of The International Cannabinoid Research Society. St. Charles, II. Usa: Pheasant Run; 2011. http://icrs.co/SYMPOSIUM.2011/ICRS2011.Final.Programme.pdf.

5. Genovese T, Esposito E, Mazzon E, Di Paola R, Meli R, Bramanti P, Piomelli D, Calignano A, Cuzzocrea S. Effects of palmitoylethanolamide on signaling pathways implicated in the development of spinal cord injury. J Pharmacol Exp Ther. 2008:326(1):12-23. https://doi.org/10.1124/jpet.108.136903.

6. Esposito E, Paterniti I, Mazzon E, Genovese T, Di Paola R, Galuppo M, Cuzzocrea S. Effects of palmitoylethanolamide on release of mast cell peptidases and neurotrophic factors after spinal cord injury. Brain Behav Immun. 2011;25(6):1099-112 https://doi.org/10.1016/j.bbi.2011.02.006.

7. Facci L, Dal Toso R, Romanello S, Buriani A, Skaper SD, Leon A. Mast cells express a peripheral cannabinoid receptor with differential sensitivity to anandamide and palmitoylethanolamide. Proc Natl Acad Sci U S A. 1995; 92(8):3376-80 7724569 .

8. Sugiura T, Kondo S, Kishimoto S, Miyashita T, Nakane S, Kodaka T, Suhara Y, Takayama H, Waku K. Evidence that 2-arachidonoylglycerol but not Npalmitoylethanolamine or anandamide is the physiological ligand for the cannabinoid CB2 receptor. Comparison of the agonistic activities of various cannabinoid receptor ligands in HL-60 cells. J Biol Chem. 2000;275(1):605-12 https://doi.org/10.1074/jbc.275.1.605January 7, 2000.

9. Costa B, Conti S, Giagnoni G, Colleoni M. Therapeutic effect of the endogenous fatty acid amide, palmitoylethanolamide, in rat acute inflammation: inhibition of nitric oxide and cyclo-oxygenase systems. $\mathrm{Br} J$ Pharmacol. 2002;137(4):413-20. https://doi.org/10.1038/sj.bjp.0704900.

10. Petrosino S, Di Marzo V. The pharmacology of palmitoylethanolamide and first data on the therapeutic efficacy of some of its new formulations. Br J Pharmacol. 2017:174(11):1349-65. https://doi.org/10.1111/bph.13580.

11. Di Marzo V, Melck D, Orlando P, Bisogno T, Zagoory O, Bifulco M, Vogel Z, De Petrocellis L. Palmitoylethanolamide inhibits the expression of fatty acid amide hydrolase and enhances the anti-proliferative effect of anandamide in human breast cancer cells. Biochem J. 2001;358(Pt 1):249-55 11485574.

12. Passavanti MB, Fiore M, Sansone P, Aurilio C, Pota V, Barbarisi M, Fierro D, Pace MC. The beneficial use of ultramicronized palmitoylethanolamide as add-on therapy to Tapentadol in the treatment of low back pain: a pilot study comparing prospective and retrospective observational arms. BMC Anesthesiol. 2017;17(1):171. https://doi.org/10.1186/s12871-017-0461-9.

13. Germini F, Coerezza A, Andreinetti L, Nobili A, Rossi PD, Mari D, Guyatt G, Marcucci M. N-of-1 randomized trials of ultra-micronized palmitoylethanolamide in older patients with chronic pain. Drugs Aging. 2017:34(12):941-52 https://doi.org/10.1007/s40266-017-0506-2.

14. Chirchiglia D, Chirchiglia P, Signorelli F. Nonsurgical lumbar radiculopathies treated with ultramicronized palmitoylethanolamide (UMPEA): a series of 100 cases. Neurol Neurochir Pol. 2018;52(1):44-7. https://doi.org/10.1016/j. pjnns.2017.11.002

15. Giammusso B, Di Mauro R, Bernardini R. The efficacy of an association of palmitoylethanolamide and alpha-lipoic acid in patients with chronic prostatitis/chronic pelvic pain syndrome: a randomized clinical trial. Arch Ital Urol Androl. 2017;89(1):17-21.

16. Tricco AC, Lillie E, Zarin W, O'Brien KK, Colquhoun H, Levac D, Moher D, Peters MDJ, Horsley T, Weeks L, Hempel S, Akl EA, Chang C, McGowan J, Stewart L, Hartling L, Aldcroft A, Wilson MG, Garritty C, Lewin S, Godfrey CM, Macdonald MT, Langlois EV, Soares-Weiser K, Moriarty J, Clifford T, Tunçalp Ö, Straus SE. PRISMA extension for scoping reviews (PRISMA-ScR): checklist and explanation. Ann Intern Med. 2018;169(7):467-73 https://doi.org/10. 7326/M18-0850

\section{Ready to submit your research? Choose BMC and benefit from:}

- fast, convenient online submission

- thorough peer review by experienced researchers in your field

- rapid publication on acceptance

- support for research data, including large and complex data types

- gold Open Access which fosters wider collaboration and increased citations

- maximum visibility for your research: over $100 \mathrm{M}$ website views per year

At BMC, research is always in progress.

Learn more biomedcentral.com/submissions 